\title{
CD73 as a therapeutic target for pancreatic neuroendocrine tumor stem cells
}

\author{
ERIKO KATSUTA $^{1,2}$, SHINJI TANAKA ${ }^{1,2}$, KAORU MOGUSHI $^{3}$, SHU SHIMADA $^{1}$, YOSHIMITSU AKIYAMA ${ }^{1}$, \\ ARIHIRO AIHARA $^{2}$, SATOSHI MATSUMURA ${ }^{2}$, YUSUKE MITSUNORI ${ }^{2}$, DAISUKE BAN ${ }^{2}$, \\ TAKANORI OCHIAI ${ }^{2}$, ATSUSHI KUDO ${ }^{2}$, HIROSHI FUKAMACHI ${ }^{1}$, HIROSHI TANAKA ${ }^{3}$, \\ KOH NAKAYAMA ${ }^{4}$, SHIGEKI ARII ${ }^{2}$ and MINORU TANABE ${ }^{2}$ \\ Departments of ${ }^{1}$ Molecular Oncology, ${ }^{2}$ Hepato-Biliary-Pancreatic Surgery, Graduate School of Medicine \\ and ${ }^{3}$ Bioinformatics, Medical Research Institute, ${ }^{4}$ Oxygen Biology Unit, Frontier Research Laboratory, \\ Medical Research Institute, Tokyo Medical and Dental University, Tokyo, Japan
}

Received September 26, 2015; Accepted November 5, 2015

DOI: 10.3892/ijo.2015.3299

\begin{abstract}
Identification and purification of cancer stem cells (CSCs) lead to the discovery of novel therapeutic targets; however, there has been no study on isolation of the CSC population among pancreatic neuroendocrine tumors (pNETs). This study aimed to identify pNET CSCs and to characterize a therapeutic candidate for pNET CSCs. We identified CSCs by aldehyde dehydrogenase (ALDH) activity in pNET clinical specimens and cell lines. We verified whether or not these cells have the stemness property in vivo and in vitro. $\mathrm{ALDH}^{\text {high }}$ cells, but not control bulk cells, formed spheres, proliferated under hypoxic condition as well as normoxic condition and promoted cell motility, which are features of CSCs. Injection of as few as $10 \mathrm{ALDH}^{\text {high }}$ cells led to subcutaneous tumor formation, and $10^{5} \mathrm{ALDH}^{\text {high }}$ cells, but not control bulk cells, established metastases in mice. Comprehensive gene expression analysis revealed that genes associated with mesenchymal stem cells, including CD73, were overexpressed in $\mathrm{ALDH}^{\text {high }}$ cells. Additionally, the in vitro and in vivo effects of an inhibitor of CD73 were investigated. The CD73 inhibitor APCP significantly attenuated in vitro sphere formation and cell motility, as well as in vivo tumor growth observed for $\mathrm{ALDH}^{\text {high }}$ cells. Finally, its expression was evaluated using clinical pNET tissue samples. Immunohistochemical analysis of clinical tissue samples demonstrated CD73 expression was significantly correlated with the invasion into adjacent organs. Since recent studies revealed CD73 as a potential biomarker of anti-PD-1 immune checkpoint therapy, CD73 might be a promising therapeutic target for pNET CSCs.
\end{abstract}

Correspondence to: Dr Shinji Tanaka, Department of Molecular Oncology, Graduate School of Medicine, Tokyo Medical and Dental University, 1-5-45 Yushima, Bunkyo-ku, Tokyo 113-8519, Japan E-mail: tanaka.monc@tmd.ac.jp

Key words: pancreatic neuroendocrine tumor, cancer stem cell, CD73, molecular target, PD-1, immune checkpoint

\section{Introduction}

The incidence and prevalence of pancreatic neuroendocrine tumors (pNETs) are being found increasingly; pNETs represent $\sim 1.3$ and $10 \%$ of pancreatic malignancy cases in incidence and in prevalence, respectively (1-3). Approximately $65 \%$ of pNET patients present with unresectable or metastatic disease (4), and in $>40 \%$ patients, recurrence or metastasis occurs even after radical surgical resection, resulting in a poor prognosis $(5,6)$. It is urgent to explore the molecular mechanisms of pNET development, progression and metastasis in order to identify new molecular targets for therapy. Indeed, there are currently only two drugs for molecular target therapy, everolimus and sunitinib, which have been approved for clinical use for pNETs.

Emerging evidence suggests that tumor metastasis and recurrence might be caused by a small subpopulation of stemness cells, so-called cancer stem cells (CSCs). CSCs promote tumor invasion and metastasis $(7,8)$, therefore, CSCs are considered to be a promising therapeutic target for cancer (9). There have been numerous investigations for identification of the CSC population based on their characteristics, including the cell surface markers, ability to exclude a fluorescent Hoechst dye, the so-called 'side population', aldehyde dehydrogenase (ALDH) activity and dormancy (10). High ALDH activity has been shown to be one of the reliable CSC markers in several types of solid tumors, including breast, skin, bladder and prostate cancer (11-13). Gaur et al reported that CSCs were identified in gastrointestinal NETs, and that they were isolated using ALDH activity and that the CSC property was verified in 2011 (14). However, there has been no study on the identification and isolation of pNET CSCs, therefore, the clinical significance and a therapeutic target remain unknown.

In this study, we isolated pNET CSCs by sorting with ALDH activity and demonstrated that these cells have the property of stemness. Additionally, in order to acquire a CSC gene profile, genome-wide gene expression analysis was performed using DNA microarray, which revealed CD73 was overexpressed in $\mathrm{ALDH}^{\text {high }}$ cells. We identified CD73 as not 
only a unique biomarker for pNET CSCs but also as a novel molecular target for pNET therapy.

\section{Materials and methods}

Patients and tissue samples. In all, 44 patients with histologically proven pNETs underwent pancreatic resection at the Tokyo Medical and Dental University Hospital between 2001 and 2013. Of them, 15 patients who underwent surgery from 2012 to 2013 were recruited for Aldeflour assay, 31 cases were randomly selected for immunohistochemical analysis. Written informed consent was obtained from the patients, and our institutional review board approved this study (no. 1080).

Cell culture and transient transfection. Human pNET cell line QGP1 was obtained from the Health Science Research Resources Bank (Osaka, Japan). A murine insulinoma cell line MIN6 was provided by Professor J. Miyazaki (Osaka University, Japan) (15). Both cell lines were used in the present experiments within 10 passages after reception. All cell cultures were routinely tested to rule out mycoplasma infection using PlasmoTest kit (InvivoGen, San Diego, CA, USA). QGP1 cells were cultured in RPMI-1640 medium (Sigma-Aldrich, St. Louis, MO, USA), supplemented with 10\% fetal bovine serum (Biological Industries, Beit Haemek, Israel) and $1 \%$ Pen/Strep (Gibco, Grand Island, NE, USA) as antibiotics. MIN6 cells were cultured in Dulbecco's modified Eagle's medium containing $25 \mathrm{mmol} / \mathrm{l}$ glucose (DMEM; Sigma-Aldrich), supplemented with $10 \%$ fetal bovine serum, $1 \%$ Pen/Strep and $\beta$-mercaptoethanol (2ME) ( $5 \mathrm{ml} / \mathrm{l}$, Wako, Osaka, Japan). All cell lines were cultivated in a humidified incubator at $37^{\circ} \mathrm{C}$ in $5 \% \mathrm{CO}_{2}$, and were collected with $0.25 \%$ trypsin-ethylene diamine tetraacetic acid (EDTA) (Gibco).

Luciferase expression plasmid pGL4.50 [luc2/CMV/ Hygro] (Promega, Madison, WI, USA) was transfected into QGP1 cells according to the manufacturer's instructions, and luciferase-expressing QGP1 cells (QGP1-Luc) were generated as described previously (16).

Aldeflour assay. A portion of a resected tumor was harvested under sterile conditions in a pathology suite and placed on ice in DMEM/F12 (Gibco) containing 10\% fetal bovine serum, care being taken to avoid contaminating adjacent normal tissue. Each specimen was mechanically dissociated with sterile scalpels, digested for $1 \mathrm{~h}$ with $10 \mathrm{mg} / \mathrm{ml}$ type IV collagenase (Sigma-Aldrich) in fresh DMEM/F12 medium containing 10\% fetal bovine serum, and then filtered through sterile $100-\mu \mathrm{m}$ membranes to obtain single-cell suspensions. Red blood cells in the surgical samples were lysed using a red blood cell lysis buffer (Miltenyi Biotec, Bergisch Gladbach, Germany). Cultured cells were collected with Accutase (BD Bioscience, San Jose, CA, USA) as single cells. An Aldefluor kit (Stemcell Technologies, Vancouver, Canada) was used to isolate the population of cells with high ALDH enzymatic activity. Cells were suspended in Aldefluor assay buffer containing ALDH substrate (BAAA, $1 \mu \mathrm{mol} / \mathrm{l}$ ) and incubated at $37^{\circ} \mathrm{C}$ for $30 \mathrm{~min}$. As a negative control, an aliquot of each sample was treated with $50 \mathrm{mmol} / \mathrm{l}$ diethyl-aminobenzaldehyde (DEAB), a specific ALDH inhibitor. The fluorescently labeled product, BODIPY-aminoacetate, was produced by cells expressing the ALDH enzyme, and ALDH ${ }^{\text {high }}$ cells were quantified and purified using FACS Aria II (BD Biosciences).

Spheroid assay. The spheroid assay was performed as described previously (16-18). After FACS sorting, ALDH ${ }^{\text {high }}$ or bulk cells were plated separately at a density of 300 cells on low attachment plates (96-well Ultra Low Cluster Plate; Costar, Corning, New York, NY, USA), and then incubated in serum-free DMEM/F12 medium ( $\mathrm{n}=20$ in each). To investigate sphere formation with the CD73 inhibitor, after FACS sorting, $5 \times 10^{4} \mathrm{ALDH}^{\text {high }}$ cells were seeded into two 6-cm dishes. After $24 \mathrm{~h}$, PBS or $12 \mu \mathrm{M} \alpha, \beta$-methylene adenosine 5'-diphosphate (APCP) (Sigma-Aldrich) was added to each dish. After $48 \mathrm{~h}$, the medium was changed to drug-free medium, followed by incubation for $24 \mathrm{~h}$. Using trypan blue exclusion, the remaining viable cells were collected and plated separately at 300 cells per low attachment plates, and then incubated in serum-free medium ( $\mathrm{n}=20$ in each). Sphere formation was observed using an AxioObserver (Carl Zeiss, Oberkochen, Germany), and images were acquired digitally using AxioVision software (Carl Zeiss). Experiments were independently performed in triplicate.

Hypoxic treatment. Hypoxic treatment was performed as described previously (18). PNET cell lines were seeded into 96-well plates at $3 \times 10^{3}$ cells per well. After $24 \mathrm{~h}$, the cells were exposed to hypoxic conditions $\left(1 \% \mathrm{O}_{2}, 5 \% \mathrm{CO}_{2}\right.$, and $94 \% \mathrm{~N}_{2}$ ) in an anaerobic workstation (Hirasawa Works, Tokyo, Japan). The oxygen concentration inside the workstation was constantly monitored with an oxygen sensor (MC-8G-S, Iijima Electrics, Gamagori, Japan) and maintained at $1 \%$ during the experiment. After 2, 4 and 6 days, the number of living cells was measured by the MTS assay using a Cell Titer 96 AQueous One Solution Cell Proliferation Assay kit (Promega), according to the manufacturer's instructions. The absorbance was read at $490 \mathrm{~nm}$, with $630 \mathrm{~nm}$ as the reference wavelength, using a multiwall plate reader (Model 550, Bio-Rad, Hercules, CA, USA), with wells containing medium but no cells serving as blank controls $(16,19)$. The experiments were independently performed in triplicate.

Scar migration assay. After FACS sorting, pNET cells, $\mathrm{ALDH}^{\text {high }}$ or bulk, were seeded into 96 -well plates at $3 \times 10^{3}$ cells per well. The cell layer was scratched, a $200-\mu 1$ pipette tip being run the full length of each well. The well was washed once with growth medium to remove cell debris. Images were taken at the time of initial wounding as well as 24,48 and $72 \mathrm{~h}$ postwounding using an INCell Analyzer 2000 (GE Healthcare, Waukesha, WI, USA). The wound area was determined using INCell Developer Toolbox software (GE Healthcare). We compared the ratio of the area at $72 \mathrm{~h}$ after scratching to that at the time of initial wounding. Experiments were independently performed in triplicate.

Tumor xenotransplantation and tumorigenicity and drug sensitivity assaying in vivo. Female NOD.CB17$\mathrm{PR} \mathrm{kdc}^{\text {Scid } / \mathrm{J}}$ mice, 16-19 $\mathrm{g}$ and aged 4-6 weeks, were purchased from Charles River Laboratory Inc. (Kanagawa, Japan). The care and use of animals were performed in accordance with institutional guidelines. Various amounts of cells ALDH $^{\text {high }}$ 
and bulk, from $10^{1}$ to $10^{4}$ cells each) were mixed with Matrigel (BD Biosciences), and then aliquots were injected subcutaneously into both flanks of mice under isoflurane anesthesia. Tumor formation was then monitored once a week. Cancer initiation frequency was calculated using L-Calc software (Stem Cell Technologies) (20) and significance was determined by Chi-square analysis using ELDA (The Walter and Eliza Hall Institute of Medical Research) (20).

The peritoneal metastatic potential of cancer cells was assessed as reported (21). Briefly, $10^{5} \mathrm{ALDH}^{\text {high }}$ pNET cells or unsorted control cells were injected intraperitoneally into mice ( $n=4$ mice per group). The mice were monitored using a luciferase-luciferin-based imaging IVIS system (Xenogen, Alameda, CA, USA) under isoflurane anesthesia. Images of the mice were taken every week for up to 14 weeks, and then the mice were euthanized by cervical dislocation. Any mice with ascites formation or a loss of body weight of $>25 \%$ were euthanized. Animal survival data were entered to the Kaplan-Meier Life Table format and presented as a cumulative survival plot. Statistical differences were analyzed by means of log-rank test. For the drug sensitivity assay, $10^{4}$ freshly sorted $\mathrm{ALDH}^{\text {high }}$ cells were used. The mice were randomly divided into 2 groups for the experiments. APCP (400 $\mu \mathrm{g} /$ tumor) or PBS was injected into the tumor twice a week after tumor cell injection. Tumor formation was monitored once a week. The tumor volume was estimated using the following equation: volume $=($ length $) \times(\text { width })^{2} / 2$. All in vivo procedures were approved by the Animal Care Committee of Tokyo Medical and Dental University.

RNA extraction and gene expression analysis. Total RNA was extracted from QGP1 freshly sorted ALDH ${ }^{\text {high }}$ cells and unsorted control cells using a RNeasy kit (Qiagen, Hilden, Germany), and the integrity of the obtained RNA was assessed using an Agilent 2100 Bioanalyzer (Agilent Technologies, Palo Alto, CA, USA). All samples had an RNA Integrity Number of $>7.0$. Anti-sense RNA was prepared from $100 \mathrm{ng}$ of total RNA using a 3' IVT Express kit (Affymetrix, Santa Clara, CA, USA). Hybridization and signal detection for HG-U133 Plus 2.0 arrays (Affymetrix) were performed according to the manufacturer's instructions. The microarray datasets for $\mathrm{ALDH}^{\text {high }}$ and unsorted control QGP1 cells were normalized simultaneously using the robust multiarray average method found in $\mathrm{R}$ statistical software (v. 2.12.1) together with the Bioconductor package. The estimated geneexpression levels were obtained as log2-transformed values. To reveal functional relationships among genes differentially expressed in $\mathrm{ALDH}^{\text {high }}$ QGP1 cells, a protein interaction network was analyzed. Genes upregulated $>1.3$-fold between $\mathrm{ALDH}^{\text {high }}$ and unsorted control QGP1 cells were included in the network. Protein interaction data obtained from BIND (http://bond.unleashedinformatics.com), Bio-GRID (http://thebiogrid.org), and HPRD (http://www.hprd.org) were downloaded from the ftp site of the National Center for Biotechnology Information (NCBI; ftp://ftp.ncbi.nih. gov/gene/GeneRIF/interactions.gz). The protein interaction network was analyzed using Cytoscape software.

Immunocytochemistry. The cells were sorted using the FACSAria II and were incubated for $24 \mathrm{~h}$ on glass slides. After fixation with $10 \%$ trichloroacetic acid for $15 \mathrm{~min}$ at $4^{\circ} \mathrm{C}$, the cells were incubated in permeabilization buffer $(0.2 \%$ Triton-PBS) for $5 \mathrm{~min}$ at room temperature. After incubation in a blocking buffer, 3\% bovine serum albumin (BSA)-PBS, for $1 \mathrm{~h}$, the slides were incubated with the primary antibodies, CD73 (IE9; 1:50; Santa Cruz, Dallas, TX, USA) for QGP1 or CD73 (C-20; 1:50; Santa Cruz) for MIN6 for another hour. The secondary antibody, Alexa Fluor 647 tetramethyl rhodamine isothiocyanate-conjugated goat anti-rabbit IgG (1:200; Sigma-Aldrich), was diluted in 3\% BSA-PBS, and then incubated with the cells for $30 \mathrm{~min}$. The Hoechst 33342 solution was added for nuclear staining. After mounting, the slides were observed under a fluorescent microscope, AxioObserver (Carl Zeiss).

Immunohistochemical analysis. Immunohistochemical analysis was performed on pNET tissue samples. For the tissue analysis, 31 samples were available, which were stained using the anti-CD73 primary antibody (IE9; Santa Cruz) at 1:50 dilution with PBS followed by reactions in an automated immunostainer (Ventana XT System; Ventana, Roche, Basel, Switzerland) using a standard DAB detection kit (Ventana, Roche). The immunostaining was evaluated quantitatively by counting $\geq 500$ cells in three different random fields under a light microscope. Tissue samples with $>5 \%$ of strong staining in the pNET tumor cells were diagnosed as positive, and the others were diagnosed as negative immunohistochemically. The immunostaining was evaluated under a light microscope by two independent investigators.

Statistical analysis. Statistical comparisons of clinicopathological characteristics for significance were performed using a Chi-square test or Fisher's exact test with a single degree of freedom, and Student's t-test was used to determine the differences between continuous values. p-values of $<0.05$ were considered to be statistically significant. All statistical analyses were performed using SPSS version 17.0 (SPSS, Chicago, IL, USA).

\section{Results}

Identification of ALDH $H^{\text {high }}$ cells in pNET specimens and cell lines. A total of 15 pNET specimens ( 7 primary lesions, 7 liver metastatic lesions and 1 lymph node metastatic lesion) were analyzed by Aldefluor assay. Flow cytometry was used to isolate viable single $\mathrm{ALDH}^{\text {high }}$ cells from $\mathrm{pNET}$ specimens, with ALDH expression greater than that of the top $0.1 \%$ of DEAB-treated negative control cells (Fig. 1A). The ALDH ${ }^{\text {high }}$ cells were observed in pNET surgical sections, the mean proportion of the subpopulation being $2.1 \pm 1.7 \%$ (range, $0.2-4.6 \%)$.

We also found a small population of cells expressing $\mathrm{ALDH}^{\text {high }}$ in pNET cell lines, QGP1 (human somatostatinoma) and MIN6 (murine insulinoma). Flow cytometric analysis revealed that $\mathrm{ALDH}^{\text {high }}$ cells represented from 1 to $4 \%$ of the population in both pNET cell lines, i.e., QGP1 and MIN6 (Fig. 1B).

CSC property of the pNET subpopulation among $A L D H^{\text {high }}$ cells in vitro. In order to investigate whether or not $\mathrm{ALDH}^{\text {high }}$ cells were characterized as CSCs, sphere-forming ability was 
A

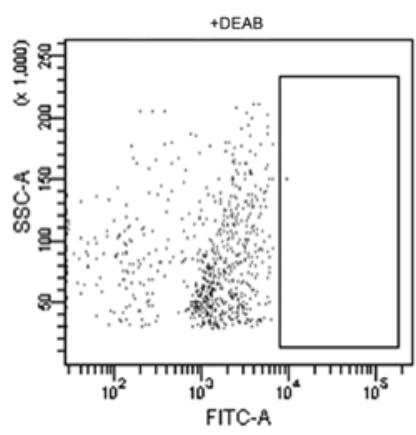

Primary lesion

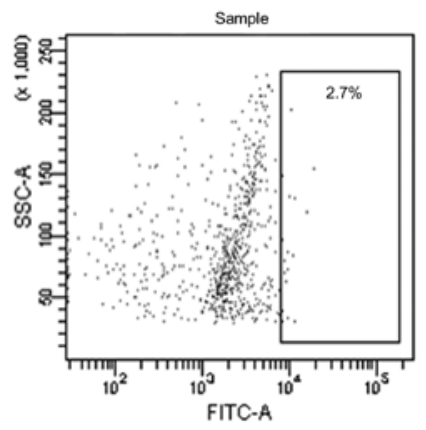

Liver metastasis
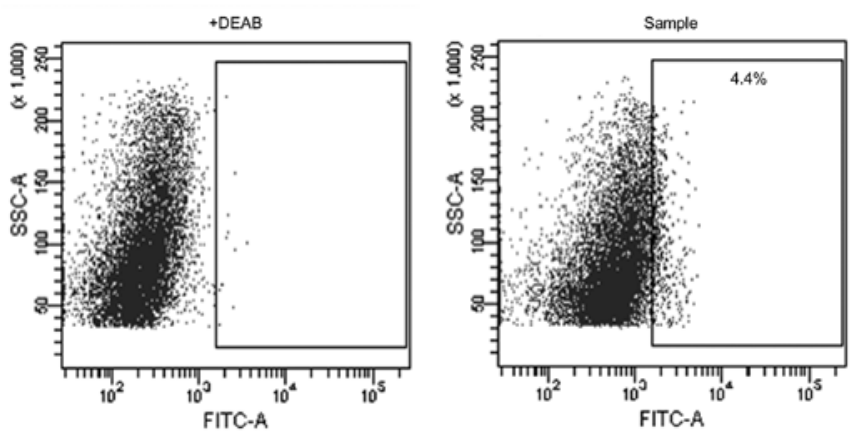

B
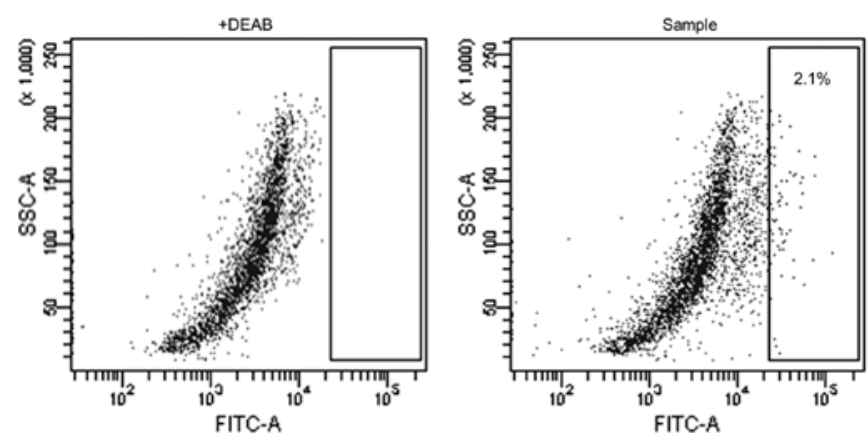

MIN6
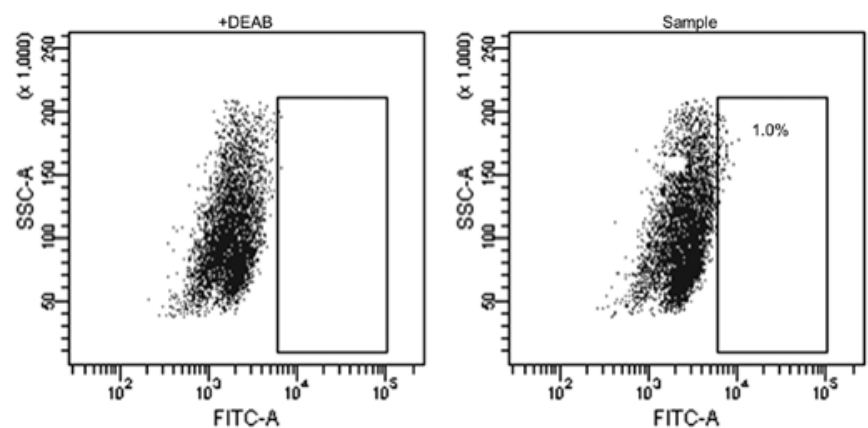

Figure 1. FACS analysis of ALDH ${ }^{\text {high }}$ cells among pNET cells. (A) $\mathrm{ALDH}^{\text {high }}$ cells are present in human surgical specimens. The ALDH ${ }^{\text {high }}$ cells are indicated by gate boxes. (B) ALDH high cells are present in pNET cell lines QGP1 and MIN6. The ALDH ${ }^{\text {high }}$ population ranges approximately from 1 to $4 \%$ of viable cells, indicated by gate boxes.

evaluated by sphere formation assay. The results showed that $\mathrm{ALDH}^{\text {high }}$ cells formed spheres in contrast to unsorted cells for both QGP1 (Fig. 2A and C; p <0.001) and MIN6 (Fig. 2B and $\mathrm{D} ; \mathrm{p}<0.001)$.

Since the pluripotent potential in embryonic stem cells is efficiently maintained under low oxygen levels (22), and hypoxia contributes to CSCs maintenance (23), the effects of hypoxic treatment on $\mathrm{ALDH}^{\text {high }}$ and unsorted pNET cells were evaluated utilizing QGP1. Cell proliferation was 39\% reduced under hypoxic conditions $\left(1 \% \mathrm{O}_{2}\right)$ compared to normoxic conditions for control cells, in contrast, no significant difference in proliferation was observed between under hypoxic and normoxic conditions for ALDH ${ }^{\text {high }}$ cells (Fig. 2E). These results are consistent with the reports showing that hypoxic conditions serve as a stimulus for reprograming cells towards normal stem cells and CSCs $(22,23)$.

To determine whether or not ALDH ${ }^{\text {high }}$ cells promote cell motility, scar migration assay was performed for QGP1. Cell motility was quantified by measuring the scratch wound closure as a percentage. There was a $20 \%$ greater reduction in wound size for ALDH ${ }^{\text {high }}$ cells than for control unsorted cells (Fig. 2F and $\mathrm{G} ; \mathrm{p}=0.006$ ).

CSC property of the pNET subpopulation among ALDH $H^{\text {high }}$ cells in vivo. Different numbers of QGP1 $\mathrm{ALDH}^{\text {high }}$ or unsorted cells were injected subcutaneously into non-obese diabetic/severe combined immunodeficient (NOD/SCID) mice in numbers ranging from $10^{1}$ to $10^{4}$ cells per injection. The results showed ALDH ${ }^{\text {high }}$ pNET cells had higher tumorigenicity than unsorted cells. Surprisingly, for a very small number of $\mathrm{ALDH}^{\text {high }}$ cells, as few as $10^{1}$ cells, subcutaneous
Table I. Fraction (\%) of injected mice that developed tumors.

\begin{tabular}{lcc}
$\begin{array}{l}\text { No. of cells } \\
\text { injected }\end{array}$ & $\begin{array}{c}\text { Injected with } \\
\text { ALDH } \\
(\%)\end{array}$ & $\begin{array}{c}\text { Injected with } \\
\text { control cells } \\
(\%)\end{array}$ \\
\hline $10^{1}$ & $1 / 6(17)$ & $0 / 6 \quad(0)$ \\
$10^{2}$ & $4 / 6(67)$ & $0 / 6 \quad(0)$ \\
$10^{3}$ & $6 / 6(100)$ & $5 / 6 \quad(83)$ \\
$10^{4}$ & $6 / 6(100)$ & $6 / 6(100)$ \\
\hline
\end{tabular}

tumor formation was observed (Fig. 3A and Table I). The cancer initiation frequency was 1 in 83 (95\% CI, 33-211) for ALDH $^{\text {high }}$ pNET cells and 1 in 720 (95\% CI, 292-1,777) for unsorted cells ( $\mathrm{p}=0.002)$. These results suggested that CSCs are enriched in the $\mathrm{ALDH}^{\text {high }}$ subpopulation.

Furthermore, to investigate whether or not the pNET cells establish in vivo metastasis, $\mathrm{ALDH}^{\text {high }}$ or unsorted pNET cells were injected intraperitoneally into a NOD/SCID mouse utilizing QGP1. Peritoneal metastasis was assessed with IVIS imaging system. ALDH ${ }^{\text {high }}$ cells $\left(10^{5}\right)$ were sufficient to establish metastasis in all transplanted mice, in contrast, no established metastasis was observed in mice transplanted with $10^{5}$ unsorted cells (Fig. 3B and C).

Genome-wide gene expression correlates to ALDH activity of pNET cells. Comprehensive gene expression analysis of ALDH $^{\text {high }}$ and unsorted control QGP1 cells was performed to 

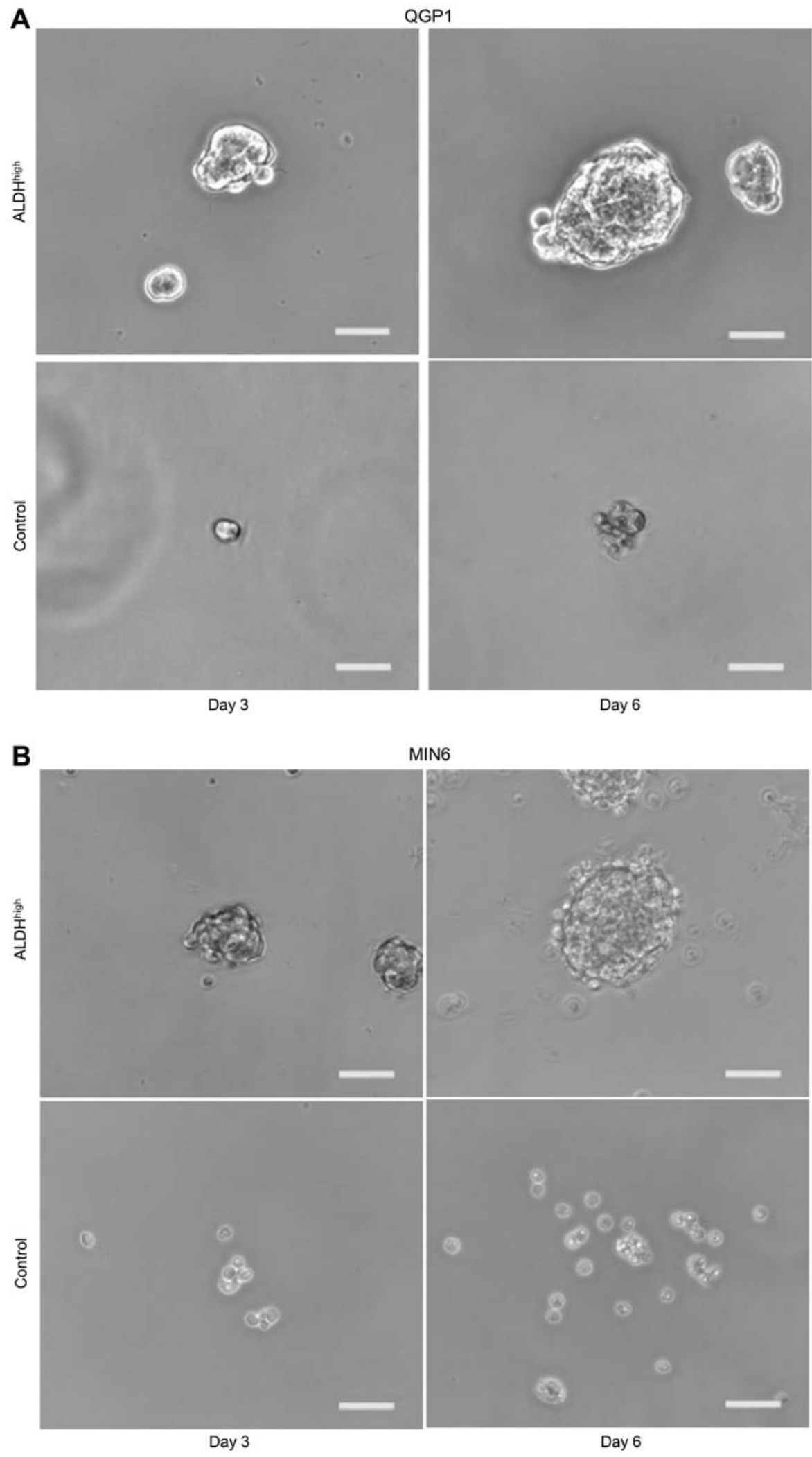

Figure 2. ALDH ${ }^{\text {high }}$ cells exhibited CSC characteristics. Representative microscopic images of spheres in ALDH ${ }^{\text {high }}$ and control cells, top and bottom, respectively, in QGP1 (A) (bars indicate $50 \mu \mathrm{m}$ ) and MIN6 (B).

acquire a CSC gene profile. The microarray data have been deposited in the Gene Expression Omnibus (GEO) database under accession number GSE62079. The gene expression changes in 185 probe sets were detected by microarray analysis (fold-change value $>2$ between $\mathrm{ALDH}^{\text {high }}$ pNET and control cells). Genes associated with mesenchymal stem cells, including CD73 (5'-nucleotidase, ecto) and CD109, and epithelial-mesenchymal transition (EMT), including caveolin-1 (CAV1) and SLUG (SNAI2), were overexpressed in $\mathrm{ALDH}^{\text {high }}$ cells. 

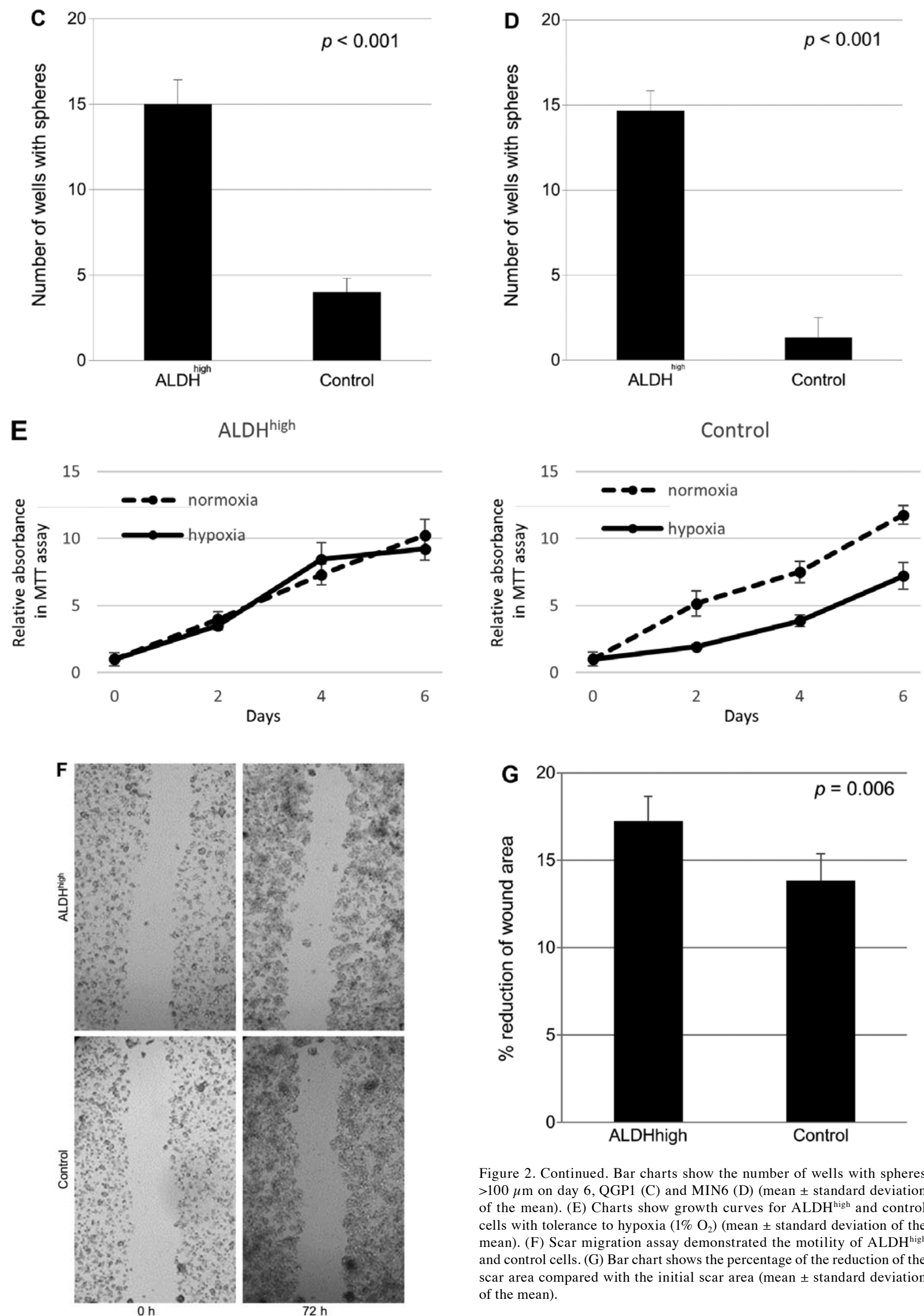

Figure 2. Continued. Bar charts show the number of wells with spheres $>100 \mu \mathrm{m}$ on day 6, QGP1 (C) and MIN6 (D) (mean \pm standard deviation of the mean). (E) Charts show growth curves for ALDH ${ }^{\text {high }}$ and control cells with tolerance to hypoxia $\left(1 \% \mathrm{O}_{2}\right)($ mean \pm standard deviation of the mean). (F) Scar migration assay demonstrated the motility of ALDH ${ }^{\text {high }}$ and control cells. (G) Bar chart shows the percentage of the reduction of the scar area compared with the initial scar area (mean \pm standard deviation of the mean). 

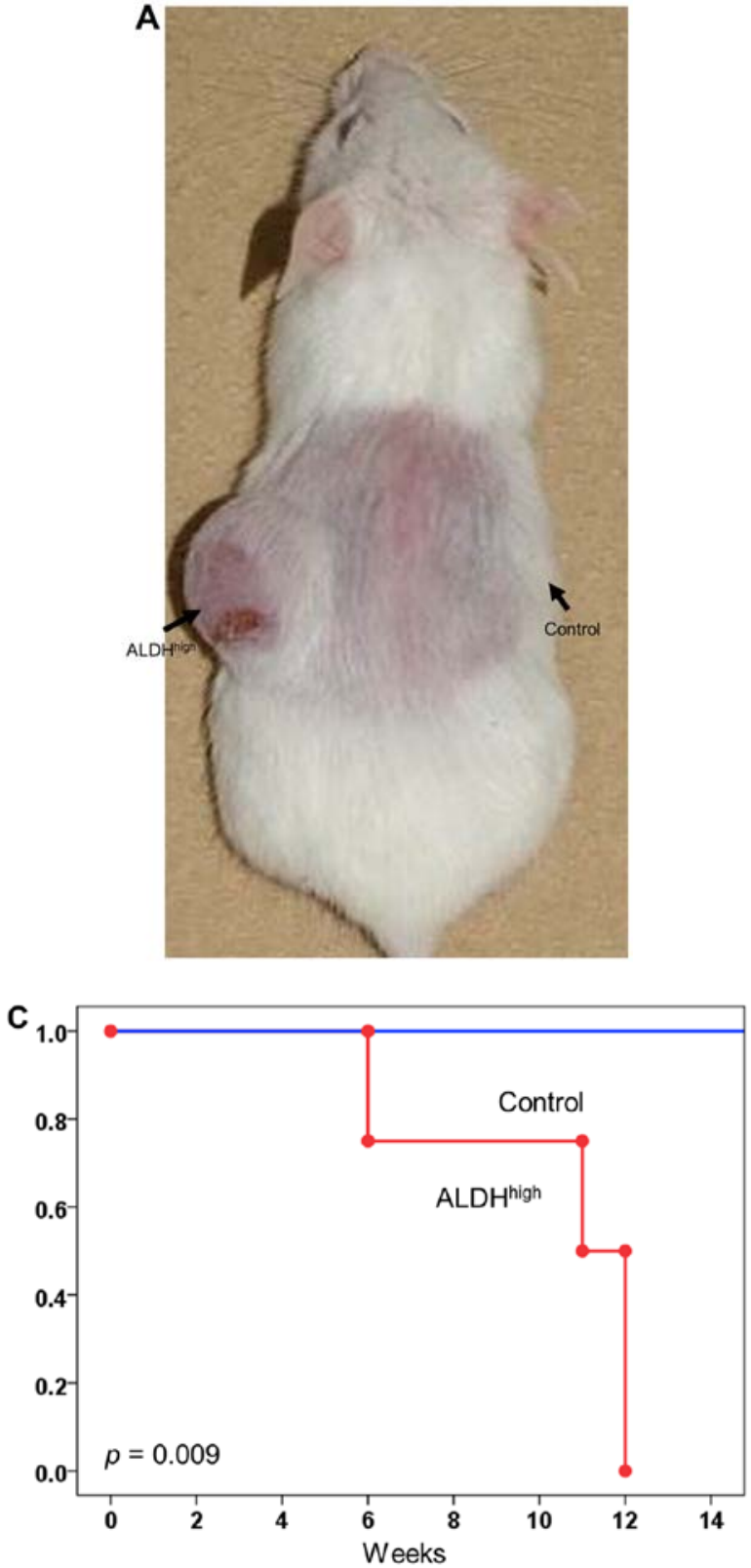
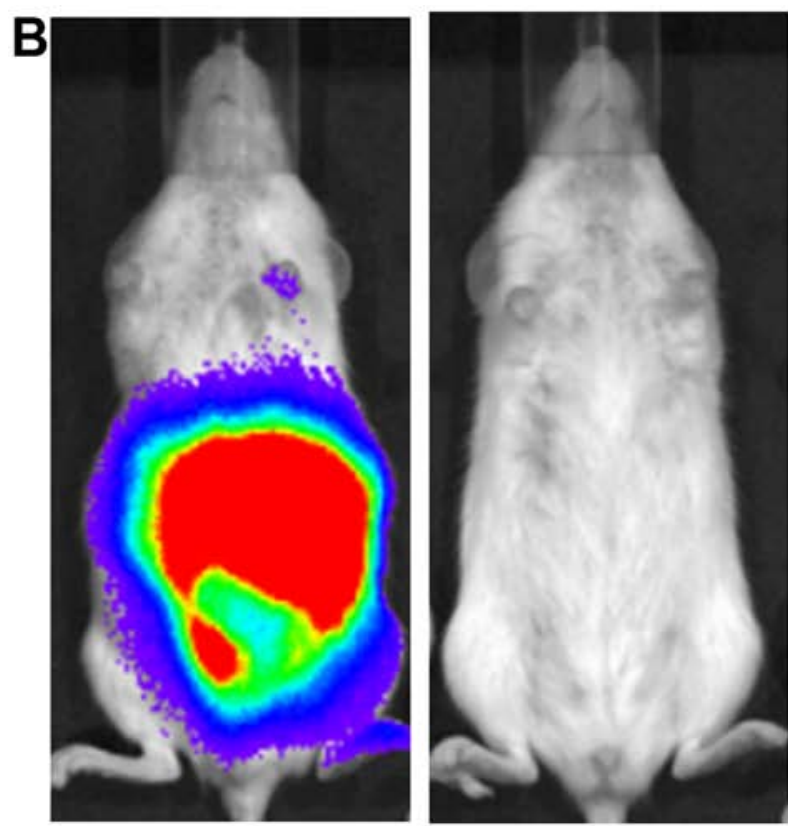

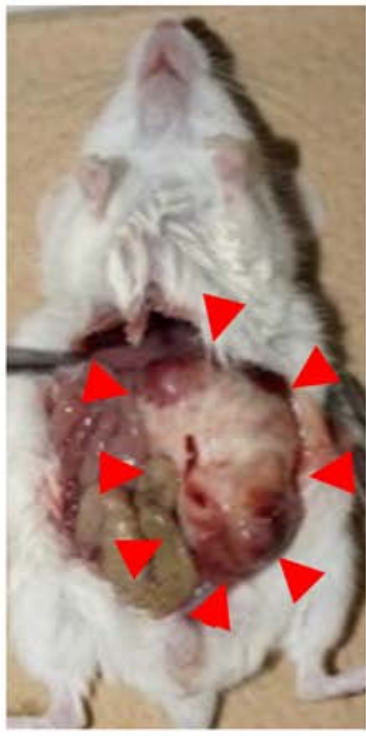

ALDH high

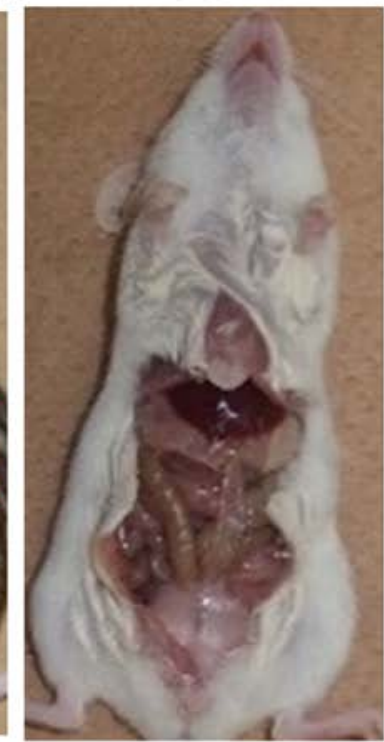

Control

Figure 3. ALDH ${ }^{\text {high }}$ cells show high tumorigenicity and enhanced metastatic potential. (A) Subcutaneous pNET tumors at 12 weeks after injection. (B) IVIS images and macroscopic appearance of peritoneal dissemination at 10 weeks after intraperitoneal injection of pNET cells. (C) Results are expressed in terms of the survival rate after injection.

A protein interaction network was then constructed using 4,438 probe sets with $\geq 1.3$-fold overexpression in $\mathrm{ALDH}^{\text {high }}$ pNET cells. To more closely investigate molecular networks associated with CSCs, a sub-network of 3-hop neighbors from the cell adhesion molecule fibronectin 1 (FN1) genes was generated, including $C D 73$ (Fig. 4), which is 12.332-fold overexperessed in $\mathrm{ALDH}^{\text {high }}$ cells compared to the unsorted control cells. On immunocytochemical analysis of QGP1 and MIN6, CD73 overexpression was observed in ALDH ${ }^{\text {high }}$ cells (Fig. 5).

Effects of a CD73 inhibitor on ALDH ${ }^{\text {high }}$ cells. We evaluated the efficacy of CD73 inhibition in ALDH ${ }^{\text {high }}$ cells of pNETs using APCP, which is a known small molecule inhibitor of $\mathrm{CD} 73$ in vitro and in vivo (2425). $\mathrm{ALDH}^{\text {high }}$ cells treated with or without APCP showed no significant difference in proliferation (data was not shown). To determine whether or not APCP inhibits the CSC properties of ALDH ${ }^{\text {high }}$ cells, sphere-forming and scar migration assay were performed for QGP1 cells. The results showed that the number of spheres was $62.2 \%$ decreased (Fig. 6A and B; $\mathrm{p}=0.002$ ) and cell motility was 39\% reduced (Fig. $6 \mathrm{C}$ and $\mathrm{D} ; \mathrm{p}=0.027$ ) on exposure to APCP in $\mathrm{ALDH}^{\text {high }}$ cells.

In order to evaluate the in vivo efficacy of APCP, peritumoral injection of APCP was performed twice a week into the QGP1 ALDH ${ }^{\text {high }}$ subcutaneous murine xenograft model. As shown in Fig. $6 \mathrm{E}$ and $\mathrm{F}, \leq 43 \%$ tumor growth inhibition was observed in the group of mice treated with APCP compared with in the control group on day $49(\mathrm{p}=0.003)$. None of the APCP-treated mice showed signs of wasting or other toxicity 


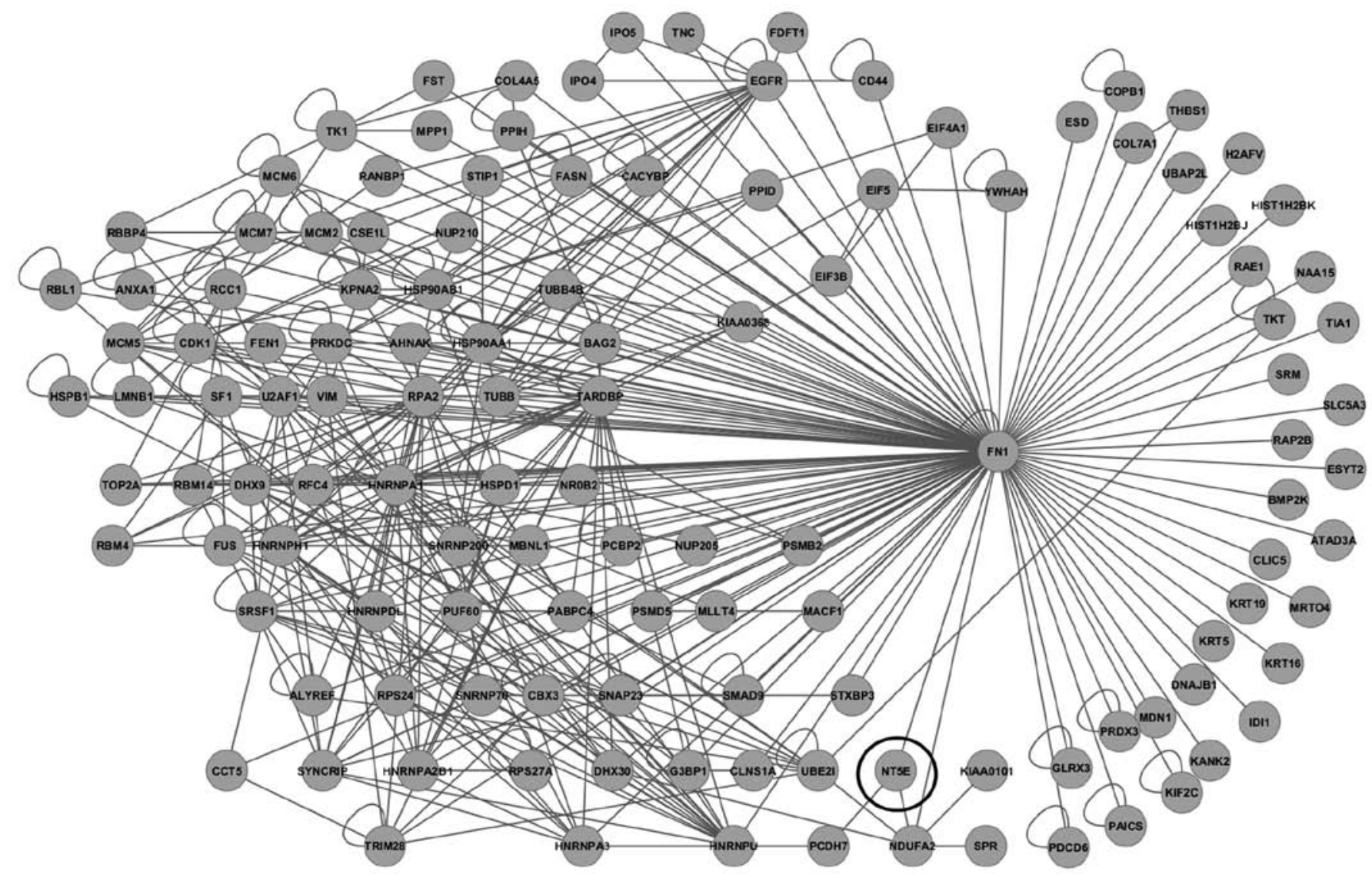

Figure 4. Molecular and biological analysis associated with $\mathrm{ALDH}^{\text {high }} \mathrm{pNET}$ cells. The profiling identified CD73 as one of the dominant molecules significantly overexpressed in $\mathrm{ALDH}^{\text {high }}$ pNET cells. A protein interaction network was constructed including CD73 using 4,438 probe sets with $>1.3$-fold change in expression ratio; a sub-network of 3-hop neighbors of FN1 was extracted.

Table II. Association of different patient and tumor specific characteristics with CD73 expression in tumor tissues.

\begin{tabular}{lccc}
\hline & CD73 low expression $(\mathrm{n}=14)$ & CD73 high expression $(\mathrm{n}=17)$ & $\mathrm{p}$-value \\
\hline Age & $53.1 \pm 14.4$ y.o. & $56.4 \pm 9.9$ y.o. & 0.483 \\
Male & $4(29 \%)$ & $9(53 \%)$ & 0.158 \\
Functionality & $4(29 \%)$ & $6(35 \%)$ & 0.497 \\
Size of primary lesion & $32.9 \pm 33.4 \mathrm{~mm}$ & $41.6 \pm 49.2 \mathrm{~mm}$ & 0.563 \\
Ki-67 index & $6.4 \pm 13.2$ & $3.3 \pm 4.2$ & 0.417 \\
Invasion into adjacent organs & $0(0 \%)$ & $6(35 \%)$ & $0.024^{\mathrm{a}}$ \\
Synchronous LNs metastasis & $2(14 \%)$ & $4(24 \%)$ & 0.429 \\
Synchronous liver metastasis & $0(0 \%)$ & $2(12 \%)$ & 0.292 \\
Synchronous peritoneal metastasis & $0(0 \%)$ & $1(6 \%)$ & 0.356 \\
\hline
\end{tabular}

${ }^{\mathrm{a}} \mathrm{p}<0.05$.

compared to control mice. APCP was tolerated at the dose at which antitumor efficacy was observed.

Expression and clinicopathological analysis of CD73 in pNET tissues. Immunohistochemical analysis of tissue samples from 31 patients with pNETs was performed to explore the clinical significance of CD73 expression. As shown in Fig. 7, the CD73 protein was mainly distributed on the cytoplasm of pNET cells. In cases of liver metastasis and peritoneal dissemination, CD73 overexpression was observed (Fig. 7C and D). Consequently, specific overexpression of CD73 was observed in 17 out of 31 cases of primary lesions $(54.8 \%)$ (Fig. 7A and B). The clinicopathological significance of CD73 expression was evaluated in the CD73-high expression group $(n=17)$, and compared to the low expression group $(n=14)$ of patients with pNETs (Table II). CD73 expression was signifi- 
A

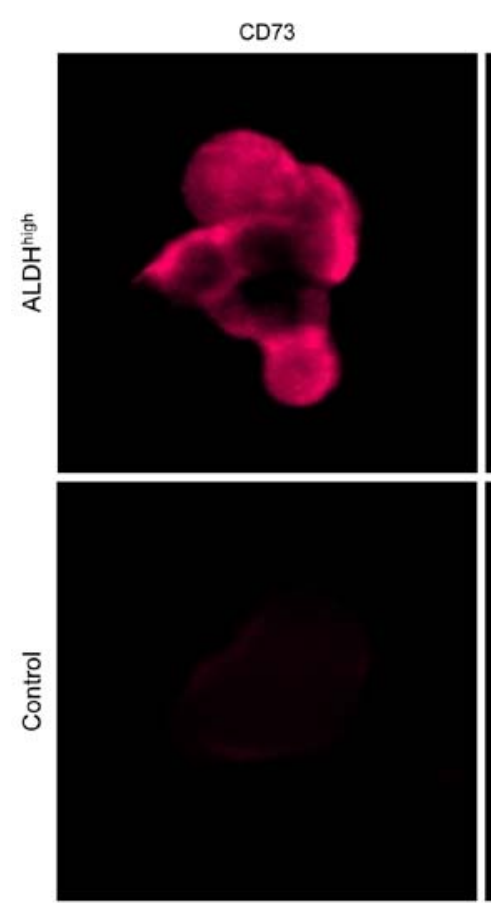

B

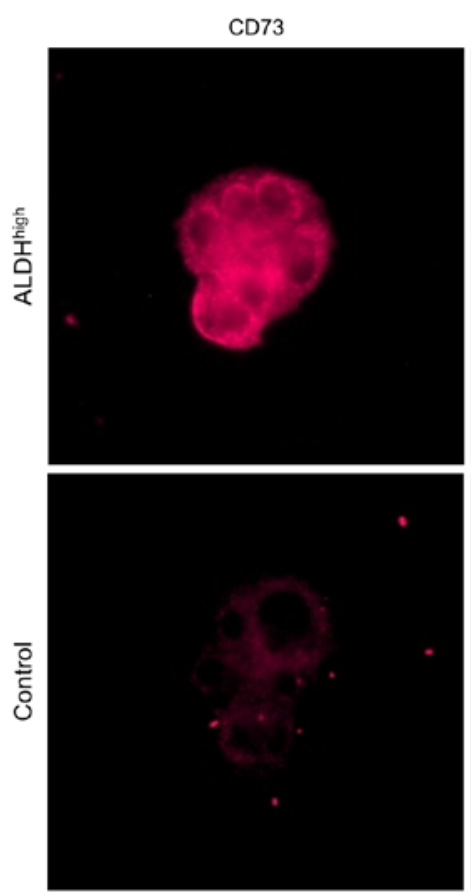

QGP1

DAPI

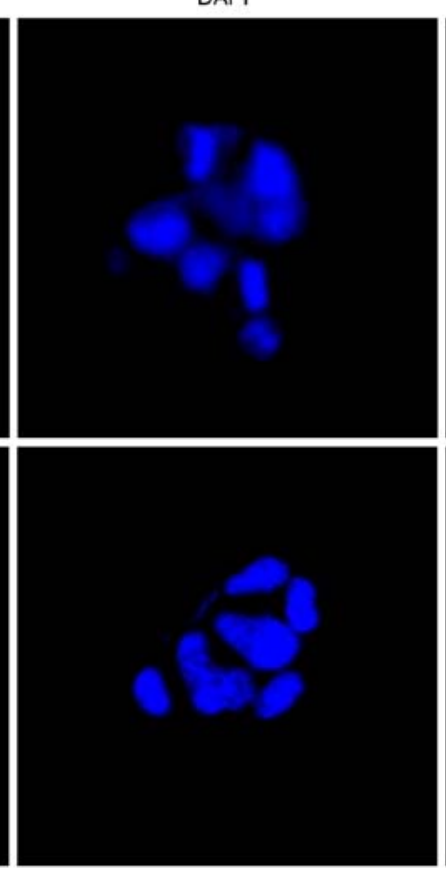

MIN6

DAPI

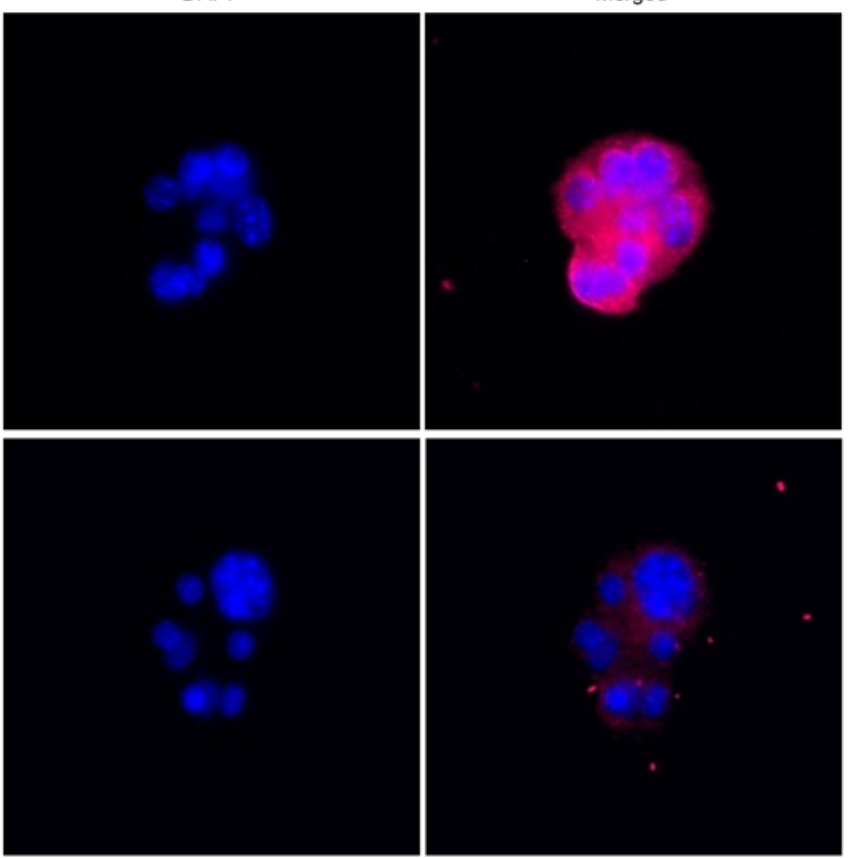

Merged
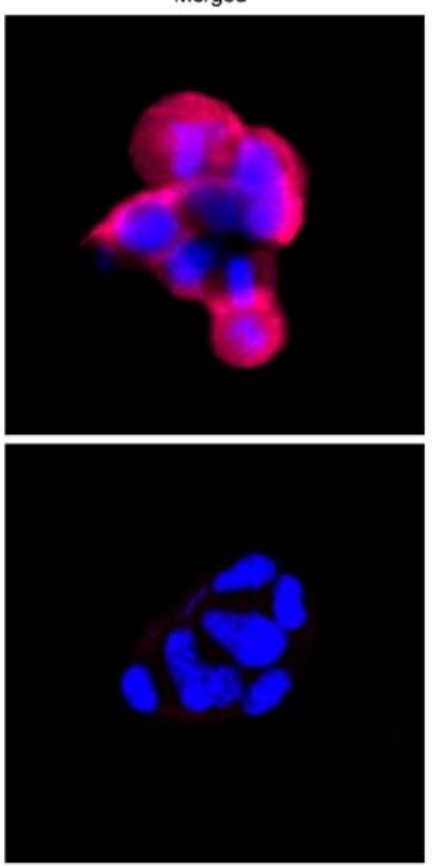

Merged

Figure 5. Immunocytochemical analysis of CD73 expression in pNET cell lines. (A) QGP1 and (B) MIN6. CD73 is located in the cytoplasm.

cantly correlated with invasion into adjacent organs $(35 \%$ vs $0 \% ; \mathrm{p}=0.024)$.

\section{Discussion}

Cancer cells include a small subpopulation of CSCs, which selectively possess tumor initiation, a self-renewal capability and the ability to give rise to bulk populations of nontumorigenic progeny through differentiation (9). In the present study, a small population of $\mathrm{ALDH}^{\text {high }}$ was observed in both clinical specimens and cell lines of pNETs, and the ALDH ${ }^{\text {high }}$ population showed the stemness feature in vitro. On the other hand, stem cell markers, such as CD44 and CD133 were not increased in the $\mathrm{ALDH}^{\text {high }}$ cells, indicating that they might not overlap completely with these populations (data not shown). Cellular spheres have been claimed to be enriched with stem cells in normal neural and mammary tissues, as well as in cancers $(16,17)$; hence, the sphere formation assay is a valuable 


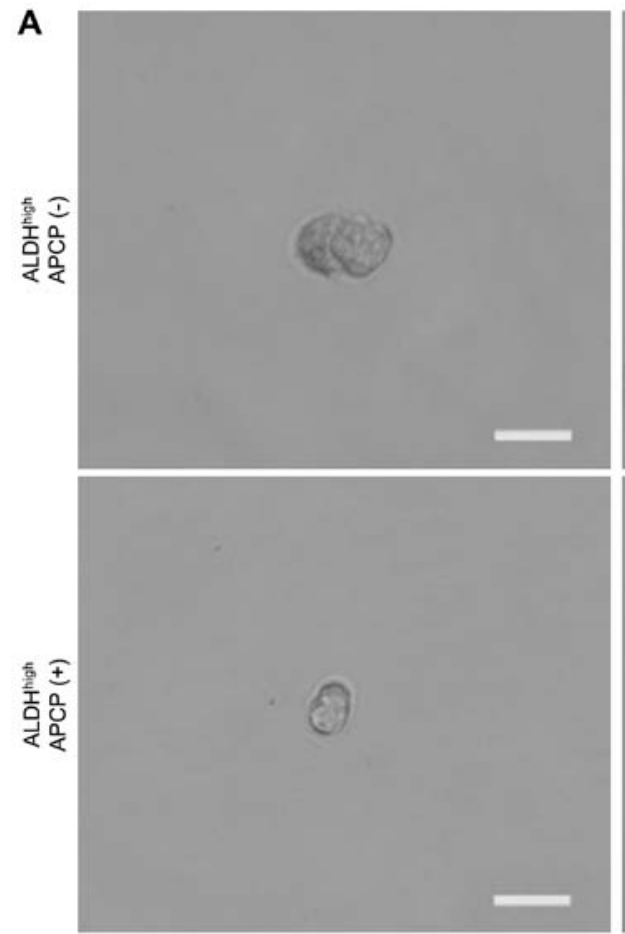

Day 3
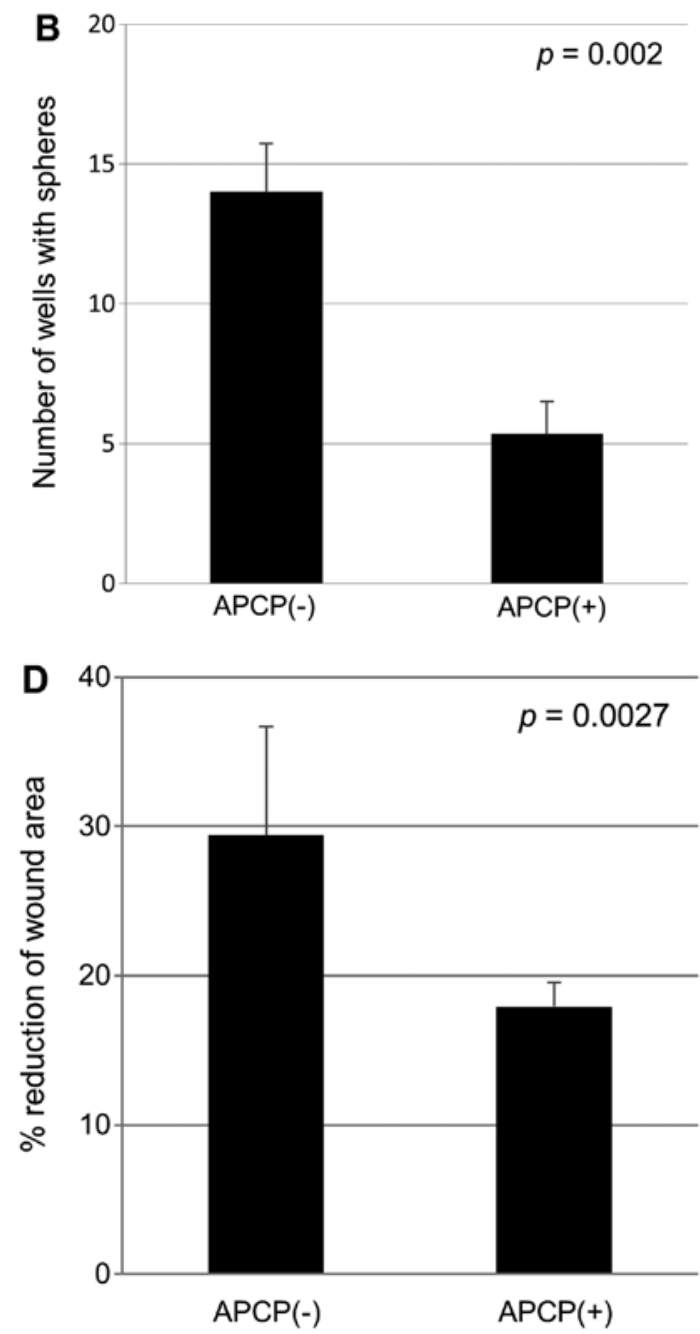
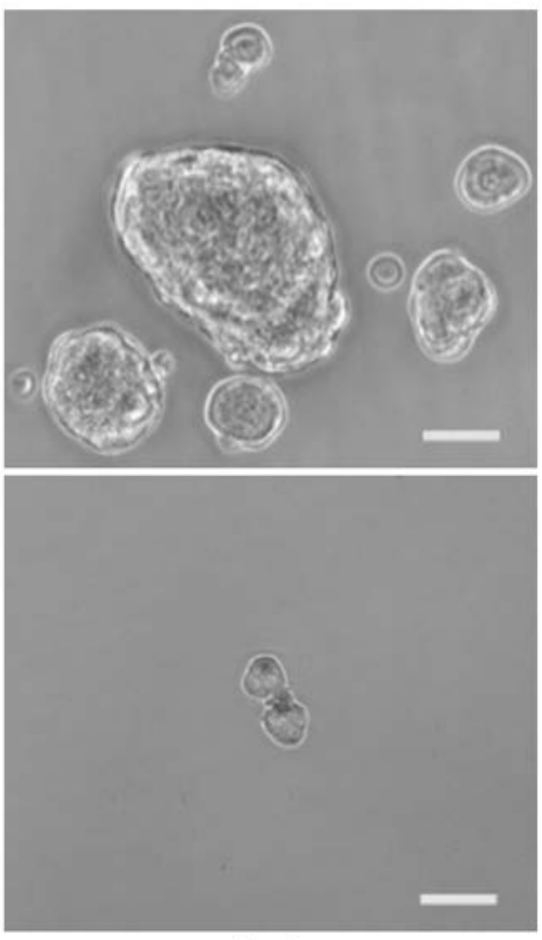

Day 6
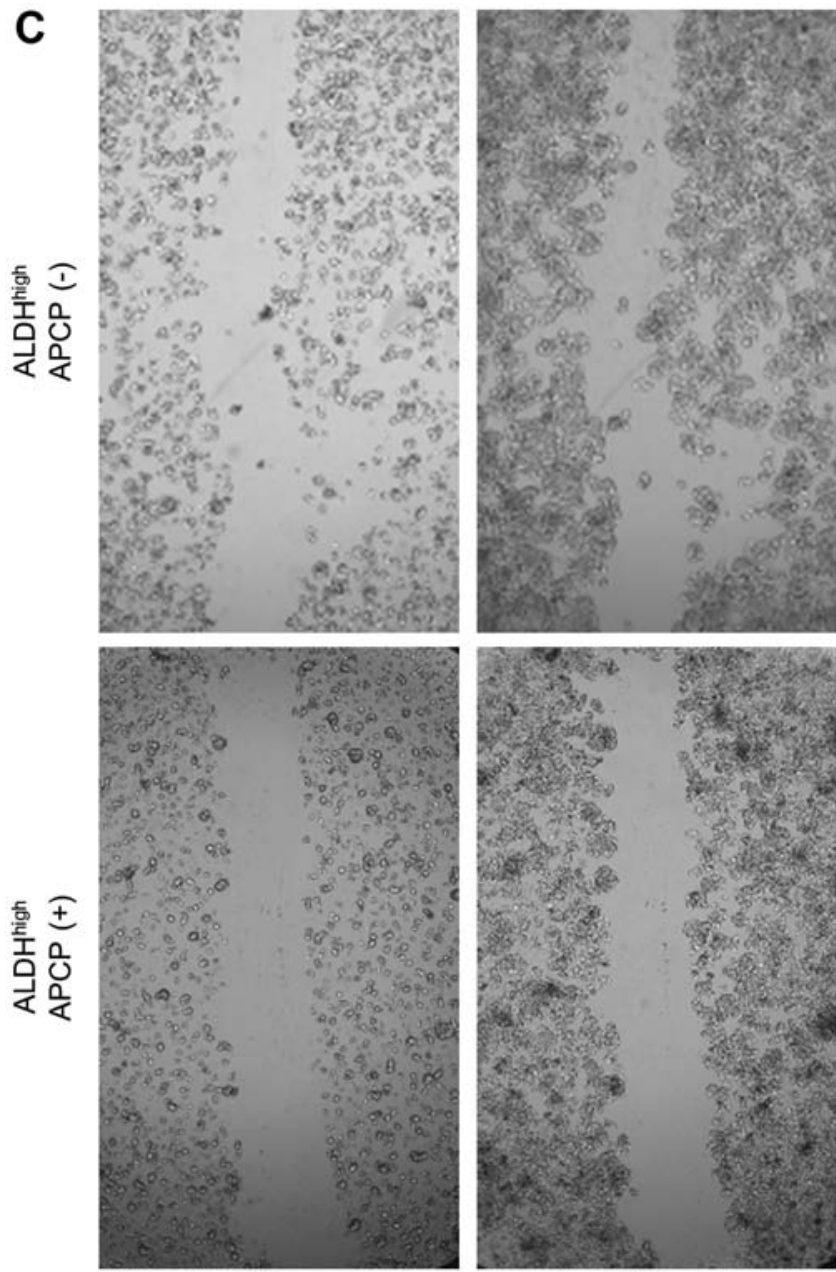

$\mathrm{Oh}$

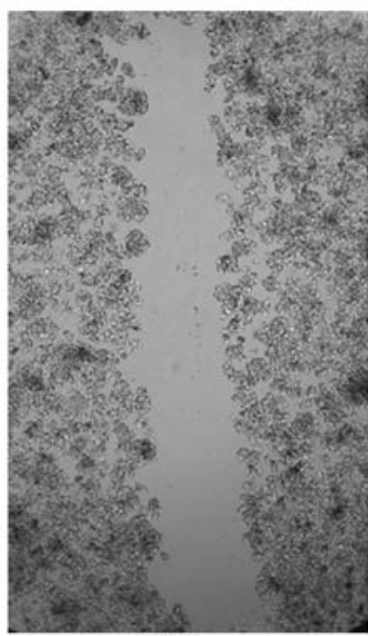

$72 \mathrm{~h}$

Figure 6. CD73 inhibitor attenuated CSC characteristics in a human pNET cell line. (A) Representative images of spheres after treatment with (bottom) or without (upper) APCP of ALDH ${ }^{\text {high }}$ cells, respectively. Bars indicate $50 \mu \mathrm{m}$. (B) Bar chart shows the number of wells with spheres of $>100 \mu \mathrm{m}$ on day 6 (mean \pm standard deviation of the mean). (C) Scar migration assay of ALDH ${ }^{\text {high }}$ cells treated with (bottom) or without (upper) APCP. (D) Bar chart shows the percentage of the reduction of the scar area compared with the initial scar area (mean \pm standard deviation of the mean). 
$\mathrm{E}$

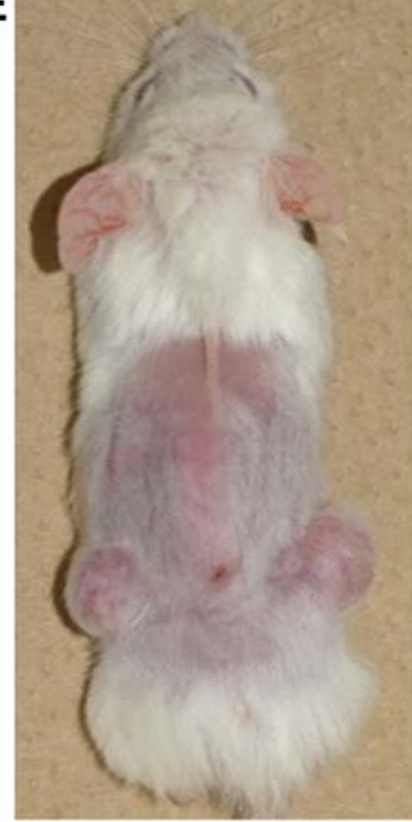

Treated with PBS

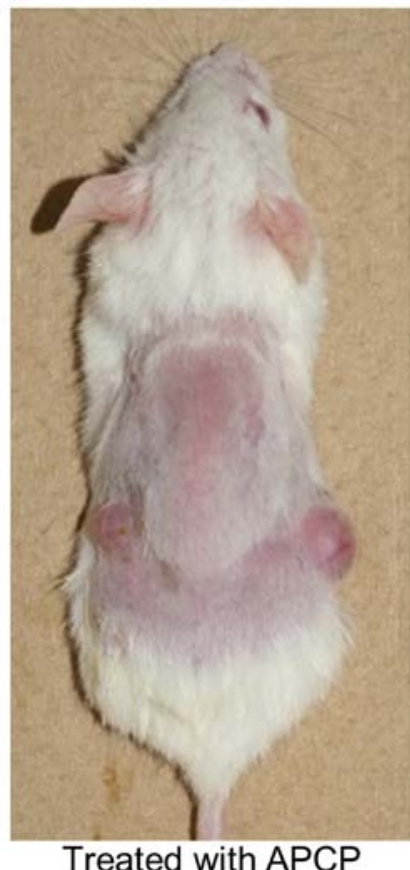

Treated with APCP
$\mathbf{F}\left(\mathrm{mm}^{3}\right)$

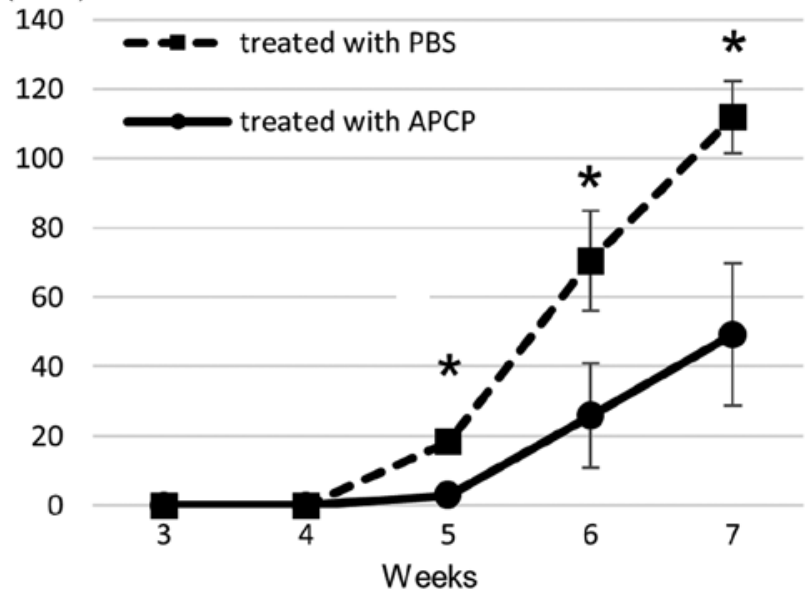

Figure 6. Continued. (E) Subcutaneous pNET tumors in NOD/SCID mice at 12 weeks after injection following treatment with APCP (right) or the control (left). (F) Comparison of the growth of subcutaneous tumors in the xenograft model that were generated from ALDH ${ }^{\text {high }}$ cells. Chart shows the tumor growth curve for treatment with or without APCP. Each plot indicates the mean tumor volumes ("p $<0.05$, mean \pm standard error of the mean).

A

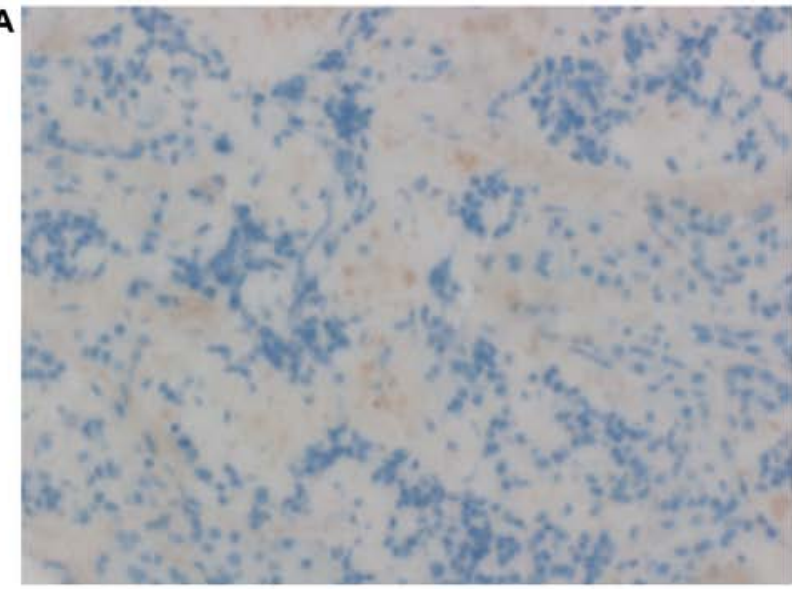

Low expression

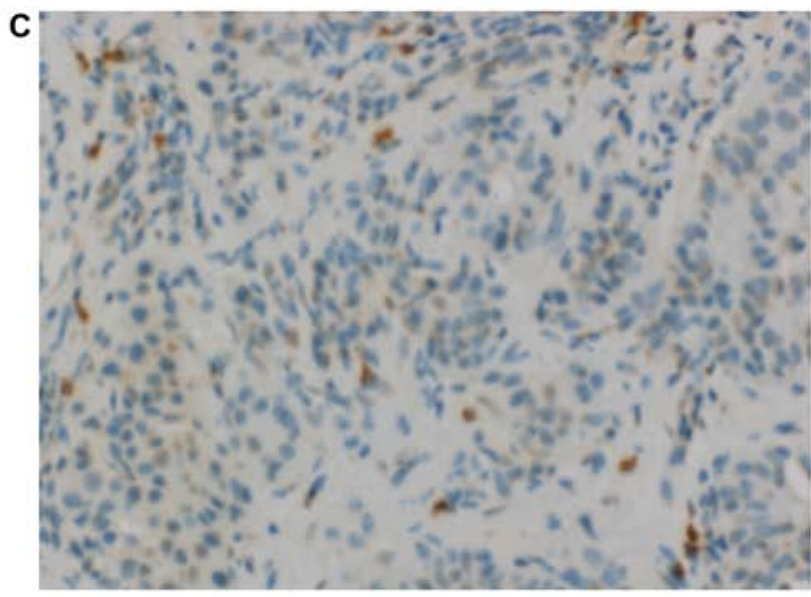

Liver metastasis

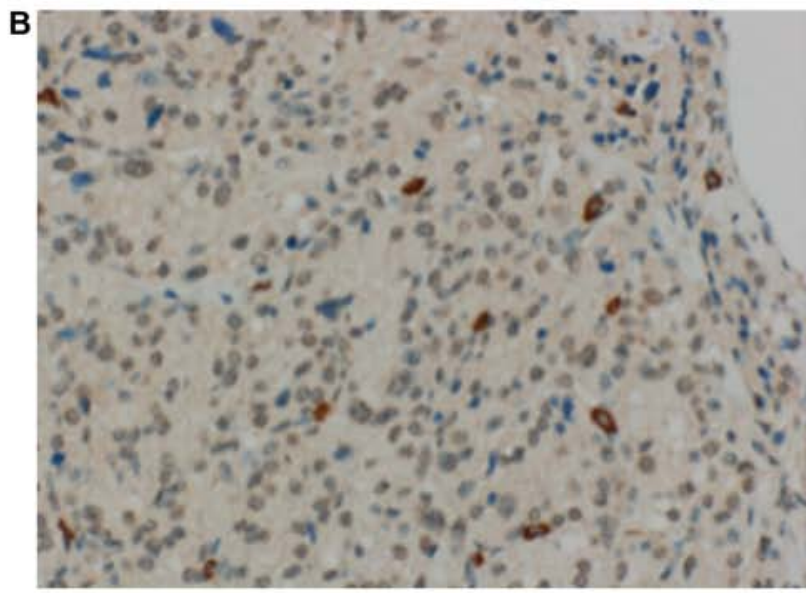

High expression

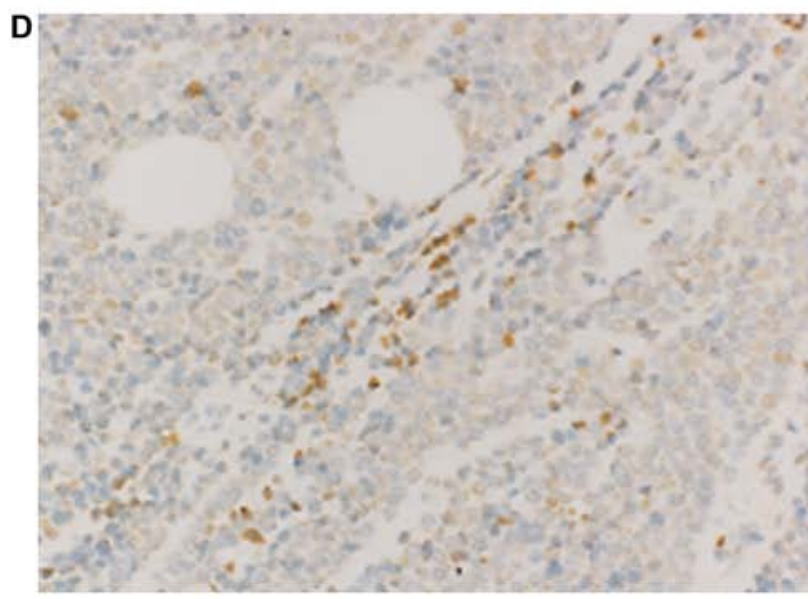

Dissemination

Figure 7. Immunohistochemical analysis of CD73 expression in pNET cases. Representative images of a CD73 low expression tumor (A) and a high expression tumor (B) are shown. Cases of liver metastasis (C) and peritoneal dissemination (D) showed overexpression of CD73. 
tool for identifying cells with the characteristics of CSCs (26). On sphere-forming assay, the number of spheres observed for unsorted bulk cells is significantly lower than that for $\mathrm{ALDH}^{\text {high }}$ cells (Fig. 2A-D). As an important feature, CSC displayed high tumorigenicity $(17,18,27), \mathrm{ALDH}^{\text {high }}$ cells showed an 9-fold higher rate of tumorigenicity than unsorted bulk cells (Fig. 3A and Table I), which suggests that CSCs were enriched in the ALDH ${ }^{\text {high }}$ population of pNETs. According to several studies, CSCs are highly resistant to hypoxia $(8,18)$, a hypoxic microenvironment maintains CSCs in a stem-like state, which leads to invasion and metastasis $(28,29)$. Metastasis and dissemination-initiating cells were found within the subpopulation of CSCs that expressed the EMT markers (10). In this study, $\mathrm{ALDH}^{\text {high }}$ cells exhibited higher resistance to hypoxia and higher motility (Fig. 2E, F and G). Moreover, these cells exhibited a higher rate of dissemination occurrence in the murine peritoneal metastasis model (Fig. 3B and C). These findings strongly suggest that ALDH ${ }^{\text {high }}$ cells of pNET have CSC features and a high malignant potential, which might be promising for therapeutic targeting for pNET treatment.

In order to explore the molecular and biological characteristics associated with $\mathrm{ALDH}^{\text {high }}$ cells, gene expression profiling was further evaluated in the pNET cell line, which revealed mesenchymal stem cell markers and EMT associated genes were overexpressed in $\mathrm{ALDH}^{\text {high }}$ pNET cell lines. We focused on CD73, also known as ecto-5'-nucleotidase (ecto5 -NT), which is a 12.332-fold overexpressed gene in ALDH ${ }^{\text {high }}$ cells. CD73 is a glycosyl-phosphatidylinositol (GPI)-linked nucleotidase present in cell membrane lipid rafts (24). CD73 is also a well-known surface marker of mesenchymal stem cells $(30,31)$, defined as a multipotent population of slow-growing, self-renewing cells (3). Bussolati et al reported that the population of CD73-overexpressed cells showed several stem cell properties: clonogenic ability, capacity of non-adhesive spheroid formation, bipotent differentiation potential into epithelial and endothelial cell types, and in vivo generation of serially transplantable carcinomas in renal cancer cells (32). Moreover, the expression of CD73, CD39 and adenosine receptors is induced by hypoxia, that is one of the most essential stemness features (33).

Overexpression of CD73 was observed in various human carcinomas, associated with tumor neovascularization, invasiveness, metastasis, and with shorter patient survival time (24). In cancer tissues, CD73 functions as a rate-limiting enzyme, together with CD39, in the generation of extracellular adenosine (34). CD39 hydrolyzes adenosine triphosphate (ATP) and adenosine diphosphate (ADP) to adenosine monophosphate (AMP), which is further hydrolyzed to adenosine by CD73 (34). Chronically increased adenosine leads to immune tolerance by accumulating in the tumor environment and stroma, and contributes to the generation of an angiogenic and matrix remodeling environment that is suitable for cancer growth. Adenosine not only functions in the tumor micro-environment, but is also involved in the regulation of proliferation, differentiation and apoptosis of cancer cells (35). The adenosine receptor activated by extracellular adenosine leads to reduction of cell adhesion and to subsequent cell scattering, and these responses promote metastasis and dissemination (35). In this study, CD73 inhibition by a small molecule inhibitor impaired the stemness property of
$\mathrm{ALDH}^{\text {high }}$ cells in pNETs including sphere-formation ability and cell motility in vitro, and significantly reduced tumor growth in the murine xenograft model of pNET.

In conclusion, the $\mathrm{ALDH}^{\text {high }}$ cell population of pNET displayed CSC characteristics in vitro and in vivo. Furthermore, CD73 might play a critical role in the maintenance and progression of ALDH ${ }^{\text {high }}$ cells, and be promising as a novel therapeutical target for pNETs. More recently, CD73 was identified as a potential biomarker of anti-PD-1 immune checkpoint therapy (36). Urgent studies on CD73 are expected to confirm that it is a target for the treatment of pNETs.

\section{References}

1. Yao JC, Eisner MP, Leary C, Dagohoy C, Phan A, Rashid A, Hassan M and Evans DB: Population-based study of islet cell carcinoma. Ann Surg Oncol 14: 3492-3500, 2007.

2. Yao JC, Hassan M, Phan A, Dagohoy C, Leary C, Mares JE, Abdalla EK, Fleming JB, Vauthey JN, Rashid A, et al: One hundred years after 'carcinoid': Epidemiology of and prognostic factors for neuroendocrine tumors in 35,825 cases in the United States. J Clin Oncol 26: 3063-3072, 2008.

3. Song L, Webb NE, Song Y and Tuan RS: Identification and functional analysis of candidate genes regulating mesenchymal stem cell self-renewal and multipotency. Stem Cells 24: 1707-1718, 2006.

4. Yao JC, Shah MH, Ito T, Bohas CL, Wolin EM, Van Cutsem E, Hobday TJ, Okusaka T, Capdevila J, de Vries EG, et al; RAD001 in Advanced Neuroendocrine Tumors, Third Trial (RADIANT-3) Study Group: Everolimus for advanced pancreatic neuroendocrine tumors. N Engl J Med 364: 514-523, 2011.

5. Strosberg JR, Cheema A, Weber JM, Ghayouri M, Han G, Hodul PJ and Kvols LK: Relapse-free survival in patients with nonmetastatic, surgically resected pancreatic neuroendocrine tumors: An analysis of the AJCC and ENETS staging classifications. Ann Surg 256: 321-325, 2012.

6. de Herder WW: Gastroenteropancreatic neuroendocrine tumors (GEP-NETs). Best Pract Res Clin Gastroenterol 26: 689-690, 2012.

7. Miletti-González KE, Chen S, Muthukumaran N, Saglimbeni GN, Wu X, Yang J, Apolito K, Shih WJ, Hait WN and RodríguezRodríguez L: The CD44 receptor interacts with P-glycoprotein to promote cell migration and invasion in cancer. Cancer Res 65: 6660-6667, 2005.

8. Hanahan D and Weinberg RA: Hallmarks of cancer: The next generation. Cell 144: 646-674, 2011.

9. Reya T, Morrison SJ, Clarke MF and Weissman IL: Stem cells, cancer, and cancer stem cells. Nature 414: 105-111, 2001.

10. Baccelli I and Trumpp A: The evolving concept of cancer and metastasis stem cells. J Cell Biol 198: 281-293, 2012.

11. Ma I and Allan AL: The role of human aldehyde dehydrogenase in normal and cancer stem cells. Stem Cell Rev 7: 292-306, 2011.

12. Ginestier C, Hur MH, Charafe-Jauffret E, Monville F, Dutcher J, Brown M, Jacquemier J, Viens P, Kleer CG, Liu S, et al: ALDH1 is a marker of normal and malignant human mammary stem cells and a predictor of poor clinical outcome. Cell Stem Cell 1: 555-567, 2007.

13. Luo Y, Dallaglio K, Chen Y, Robinson WA, Robinson SE, McCarter MD, Wang J, Gonzalez R, Thompson DC, Norris DA, et al: ALDH1A isozymes are markers of human melanoma stem cells and potential therapeutic targets. Stem Cells 30: 2100-2113, 2012.

14. Gaur P, Sceusi EL, Samuel S, Xia L, Fan F, Zhou Y, Lu J, Tozzi F, Lopez-Berestein G, Vivas-Mejia P, et al: Identification of cancer stem cells in human gastrointestinal carcinoid and neuroendocrine tumors. Gastroenterology 141: 1728-1737, 2011.

15. Miyazaki J, Araki K, Yamato E, Ikegami H, Asano T, Shibasaki Y, Oka Y and Yamamura K: Establishment of a pancreatic beta cell line that retains glucose-inducible insulin secretion: Special reference to expression of glucose transporter isoforms. Endocrinology 127: 126-132, 1990.

16. Ogawa K, Tanaka S, Matsumura S, Murakata A, Ban D, Ochiai T, Irie T, Kudo A, Nakamura N, Tanabe M, et al: EpCAM-targeted therapy for human hepatocellular carcinoma. Ann Surg Oncol 21: 1314-1322, 2014. 
17. Adikrisna R, Tanaka S, Muramatsu S, Aihara A, Ban D, Ochiai T, Irie T, Kudo A, Nakamura N, Yamaoka S, et al: Identification of pancreatic cancer stem cells and selective toxicity of chemotherapeutic agents. Gastroenterology 143: 234-45.e7, 2012.

18. Muramatsu S, Tanaka S, Mogushi K, Adikrisna R, Aihara A, Ban D, Ochiai T, Irie T, Kudo A, Nakamura N, et al: Visualization of stem cell features in human hepatocellular carcinoma reveals in vivo significance of tumor-host interaction and clinical course. Hepatology 58: 218-228, 2013.

19. Yoshitake K, Tanaka S, Mogushi K, Aihara A, Murakata A, Matsumura S, Mitsunori Y, Yasen M, Ban D, Noguchi N, et al: Importin- $\alpha 1$ as a novel prognostic target for hepatocellular carcinoma. Ann Surg Oncol 18: 2093-2103, 2011.

20. Ishizawa K, Rasheed ZA, Karisch R, Wang Q, Kowalski J, Susky E, Pereira K, Karamboulas C, Moghal N, Rajeshkumar NV, et al: Tumor-initiating cells are rare in many human tumors. Cell Stem Cell 7: 279-282, 2010.

21. Tanaka S, Pero SC, Taguchi K, Shimada M, Mori M, Krag DN and Arii S: Specific peptide ligand for Grb7 signal transduction protein and pancreatic cancer metastasis. J Natl Cancer Inst 98 491-498, 2006.

22. Yoshida Y, Takahashi K, Okita K, Ichisaka T and Yamanaka S Hypoxia enhances the generation of induced pluripotent stem cells. Cell Stem Cell 5: 237-241, 2009.

23. Li Z, Bao S, Wu Q, Wang H, Eyler C, Sathornsumetee S, Shi Q, Cao Y, Lathia J, McLendon RE, et al: Hypoxia-inducible factors regulate tumorigenic capacity of glioma stem cells. Cancer Cell 15: 501-513, 2009.

24. Zhang B: CD73: A novel target for cancer immunotherapy. Cancer Res 70: 6407-6411, 2010.

25. Stagg J, Divisekera U, McLaughlin N, Sharkey J, Pommey S, Denoyer D, Dwyer KM and Smyth MJ: Anti-CD73 antibody therapy inhibits breast tumor growth and metastasis. Proc Nat Acad Sci USA 107: 1547-1552, 2010.

26. Chojnacki A and Weiss S: Production of neurons, astrocytes and oligodendrocytes from mammalian CNS stem cells. Nat Protoc 3: 935-940, 2008.
27. Yang ZF, Ho DW, Ng MN, Lau CK, Yu WC, Ngai P, Chu PW, Lam CT, Poon RT and Fan ST: Significance of CD $90^{+}$cancer stem cells in human liver cancer. Cancer Cell 13: 153-166, 2008.

28. Keith B and Simon MC: Hypoxia-inducible factors, stem cells, and cancer. Cell 129: 465-472, 2007.

29. Mimeault M and Batra SK: Hypoxia-inducing factors as master regulators of stemness properties and altered metabolism of cancer- and metastasis-initiating cells. J Cell Mol Med 17: 30-54, 2013.

30. Mahmood A, Harkness L, Abdallah BM, Elsafadi M, Al-Nbaheen MS, Aldahmash A and Kassem M: Derivation of stromal (skeletal and mesenchymal) stem-like cells from human embryonic stem cells. Stem Cells Dev 21: 3114-3124, 2012.

31. Chamberlain G, Fox J, Ashton B and Middleton J: Concise review: mesenchymal stem cells: their phenotype, differentiation capacity, immunological features, and potential for homing. Stem Cells 25: 2739-2749, 2007.

32. Bussolati B, Bruno S, Grange C, Ferrando U and Camussi G: Identification of a tumor-initiating stem cell population in human renal carcinomas. FASEB J 22: 3696-3705, 2008.

33. Eltzschig HK, Köhler D, Eckle T, Kong T, Robson SC and Colgan SP: Central role of Sp1-regulated CD39 in hypoxia/ ischemia protection. Blood 113: 224-232, 2009.

34. Stagg J and Smyth MJ: Extracellular adenosine triphosphate and adenosine in cancer. Oncogene 29: 5346-5358, 2010.

35. Antonioli L, Blandizzi C, Pacher P and Haskó G: Immunity, inflammation and cancer: A leading role for adenosine. Nat Rev Cancer 13: 842-857, 2013.

36. Beavis PA, Slaney CY, Milenkovski N, Henderson MA, Loi S, Stagg J, Kershaw MH and Darcy PK: CD73: A potential biomarker for anti-PD-1 therapy. OncoImmunology 4: e1046675, 2015. 